\title{
USABLE AGRICULTURAL AREA OF FARMS AND THEIR MATERIAL AND ENERGY EXPENDITURE EFFICIENCY
}

\author{
Kamil Depo ${ }^{\mathrm{a}}$, Agnieszka Szparaga ${ }^{\mathrm{b}}$, Miroslav Pristavka ${ }^{\mathrm{c}}$, Sławomir Kocira ${ }^{\mathrm{d}}$
}

a School Complex in Ludwin, 21-075 Ludwin 30a, Poland, e-mail: kil38@wp.pl

b Department of Agrobiotechnology, Koszalin University of Technology, Koszalin, Poland, e-mail: agnieszka.szparaga@tu.koszalin.pl, ORCID 0000-0001-9153-7783

c Department of Quality and Engineering Technologies, Slovak University of Agriculture in Nitra, Slovak Republic e-mail: miroslav.pristavka@uniag.sk, ORCID 0000-0002-7957-4765

${ }^{\mathrm{d}}$ Department of Machinery Exploitation and Management of Production Processes, University of Life Sciences in Lublin, Lublin, Poland; slawomir.kocira@up.lublin.pl, ORCID 0000-0002-2888-3023

*Corresponding author: e-mail: kil38@wp.pl

\begin{tabular}{|c|c|}
\hline ARTICLE INFO & ABSTRACT \\
\hline $\begin{array}{l}\text { Article history: } \\
\text { Received: January } 2020 \\
\text { Received in the revised form: } \\
\text { February } 2020 \\
\text { Accepted: March } 2020 \\
\end{array}$ & \multirow{2}{*}{$\begin{array}{l}\text { The paper analyzes the efficiency of material and energy expenditure in } \\
679 \text { farms with agricultural production as the main source of income for } \\
\text { the years 2013-2015. Six groups of farms were identified according to } \\
\text { usable agricultural area (UAA). The aim of the work was to determine } \\
\text { the impact of UAA of farms on their material and energy expenditure } \\
\text { efficiency. It was found that the area of UAA determines the farms' } \\
\text { material and energy expenditure efficiency. It was observed that small } \\
\text { farms with UAA of } 5 \text { to } 10 \text { ha are characterized by the highest material } \\
\text { and energy expenditure efficiency. It was proven that the material and } \\
\text { energy expenditure efficiency in "Small" farms with UAA ( }<=5 \text { ha) and } \\
\text { "Very large", with UAA ( }>50 \text { ha) differs significantly from the effi- } \\
\text { ciency determined for other farm groups. Material and energy expendi- } \\
\text { tures were used the least efficiently in the farms with the smallest UAA. }\end{array}$} \\
\hline $\begin{array}{l}\text { Key words: } \\
\text { material expenditure, } \\
\text { energy expenditure, } \\
\text { efficiency indexes }\end{array}$ & \\
\hline
\end{tabular}

\section{Introduction}

The last several years saw an increase in usable agricultural area (UAA) of farms, The process was accompanied by technical and technological modernization, which significantly impacted the amount of material and energy expenditure (Kocira, 2013). The amount of expenditure incurred may indicate the size of the farm and its economic strength. The level of investment expenditure may indicate strong links between the farm and its environment (Cooper et alt., 2007; Gołębiewska, 2007; Mohammadi and Omid, 2010). Material expenditure on agricultural production determine its current total cost, as well as the obtained income and the level of remuneration for the farmer and his family.

An indispensable element of production is direct and indirect energy expenditure. Direct expenditure includes fuel and electricity consumption and energy expenditures related to production of raw materials constitute indirect expenditures (Kocira et al. 2019, Pawlak, 2016). Energy holds a key share in agricultural production expenditure. Changes in the level and 
technology of agricultural production, increased prices of energy carriers and a decreasing number of entities that qualify for the category of agricultural holdings have had a significant impact on energy consumption. The development of agricultural production is associated with an increase in energy demand, especially during agrotechnical treatments (Gorzelany, 2010; Gorzelany et al., 2011; Hosseinzadeh-Bandbafha et al., 2018).

The most reliable measure to estimate the condition of the energy economy is the energy expenditure efficiency, expressed by the ratio of the value of production obtained to the expenditure incurred on fuel and electricity. One of the most important factors affecting the efficiency of energy expenditure in agricultural production is the systematically rising prices of the media. Detailed monitoring of changes in this efficiency level is also an important issue (Gorzelany, 2010; Gorzelany et al., 2011). In the case of agriculture in Poland, improving this efficiency is extremely important, primarily due to the competition from Western European farms (Ozkan et al., 2004; Sorensen et al., 2014; Wójcicki and Rudeńska, 2014; Apergis et al., 2015; Komorowska, 2016; Koesling et al., 2017).

However, more extensive studies and analyzes discussing the efficiency of material and energy expenditure on farms with different UAAs are not available. Therefore, it is justified to analyze the impact of UAA on the efficiency of material and energy expenditure to answer the question whether the UAAs of family farms differentiates the efficiency of material and energy expenditure.

\section{Material and methods}

The materials used in the work are data obtained under the Polish FADN in 2013, 2014 and 2015 from family farms located in the Lubelskie province. The research used results from 679 farms whose main source of income was agricultural production.

Farms were divided into 6 groups, according to UAA:

- "Very small" farms, with UAA $\leq 5$ ha,

- "Small" farms, with UAA $\leq 10$ ha,

- "Medium-small" farms, with UAA $\leq 20$ ha,

- "Medium-large" farms, with UAA $\leq 30$ ha,

- "Large" farms, with UAA $\leq 50$ ha,

- "Very large" farms, with UAA $\leq 50$ ha.

The analysis of the efficiency of energy and material expenditure was made using 5 indexes.

Efficiency of material and energy expenditure $\mathrm{I}\left(\mathrm{E}_{\mathrm{Nmel}}\right)$ - a ratio of total production $\left(\mathrm{P}_{\mathrm{o}}\right)$ to the sum of material and energy expenditure $\left(\mathrm{N}_{\mathrm{me}}\right)$.

$$
E_{\text {NmeI }}=\frac{P_{o}}{N_{m e}}
$$

where:

$\mathrm{P}_{\mathrm{o}} \quad$-- total production, (PLN)

$\mathrm{N}_{\mathrm{me}}-$ total material and energy expenditure, (PLN)

Total production is the sum of values of plant, animal and other types of production, e.g. own consumption. It comprises sales, transfer to a household, the farm's own consumption, 
a difference in inventory and a difference in the value of animals caused by a change in pricing and reduced by the purchase of animals.

Total expenditure is the sum of human and objectified labor used to produce a specific product or service. They can be measured in natural units or expressed as a value. Total expenditure includes: seeds and seedlings, own seeds and seedlings, fertilizers, plant protection products, feeds for animals kept in the grazing system, feeds for animals fed in the grazing system produced on farms, feeds for granivorous animals produced on farms, electricity.

Efficiency of material and energy expenditure II ( $\left.\mathrm{E}_{\mathrm{NmeII}}\right)$ - a ratio of gross value added $\left(\mathrm{W}_{\mathrm{Db}}\right)$ to total expenditure $\left(\mathrm{N}_{\mathrm{me}}\right)$.

$$
E_{N m e I I}=\frac{W_{D b}}{N_{m e}}
$$

where:

$\mathrm{W}_{\mathrm{Db}}-$ gross value added, (PLN)

$\mathrm{N}_{\mathrm{me}} \quad$ - total material and energy expenditure, (PLN)

Gross value added is the value of total production of the farm minus intermediate consumption (i.e. direct and general economic costs), balance of current payments and taxes.

Efficiency of material and energy expenditure III $\left(\mathrm{E}_{\mathrm{NmeIII}}\right)$ - a ratio of net value added $\left(\mathrm{W}_{\mathrm{Dn}}\right)$ to total expenditure $\left(\mathrm{N}_{\mathrm{me}}\right)$ :

$$
E_{N m e I I I}=\frac{W_{D n}}{N_{m e}}
$$

where:

$\mathrm{W}_{\text {Dn }} \quad-$ net value added (PLN),

$\mathrm{N}_{\mathrm{me}} \quad-$ total material and energy expenditure (PLN).

The net value added is the remuneration for work, management and capital used on the farm. It is lower than the gross value by the amount of depreciation charges.

Efficiency of material and energy expenditure IV $\left(\mathrm{E}_{\mathrm{NmelV}}\right)$ - a ratio of net agricultural income $\left(\mathrm{D}_{\mathrm{rn}}\right)$ to the sum of material and energy expenditure $\left(\mathrm{N}_{\mathrm{me}}\right)$.

$$
E_{N m e I V}=\frac{D_{r n}}{N_{m e}}
$$

where:

$\mathrm{D}_{\mathrm{rn}}-$ net agricultural income, (PLN)

$\mathrm{N}_{\mathrm{me}}$ - total material and energy expenditure, (PLN)

Net agricultural income is a direct surplus minus indirect costs

Material and energy expenditure efficiency $\mathrm{V}\left(\mathrm{E}_{\mathrm{NmeV}}\right)$ - a ratio of a farmer's family income $\left(D_{\text {rr }}\right)$ to total expenditure $\left(\mathrm{N}_{\mathrm{me}}\right)$

$$
E_{\text {NmeV }}=\frac{D_{R r}}{N_{m e}}
$$

where:

$\mathrm{D}_{\mathrm{rr}} \quad$ - the farmer's family income, (PLN)

$\mathrm{N}_{\mathrm{me}} \quad-$ total material and energy expenditure, (PLN) 
According to EU agricultural accountancy system FADN, the income of a farmer's family is the value of production (comprising the value of sales, an increase in the value of the herd, the value of productive consumption of own products, the value of private consumption of own products, the value of own product stocks at the end of the year minus the value of own products at the beginning of the year, as well as the value of the purchased animals) minus intermediate consumption.

For each expenditure efficiency index (mean values of the indexes from 2013-2015), the significance of differences between individual groups of farms was analyzed. After determining the significance of differences by the Kruskal-Wallis test at $\mathrm{p}<0.05$, a Mann-Whitney test was performed in order to assess the groups between which there are significant differences.

\section{Results and discussion}

The studied farms were characterized by a wide range of UAA, from 2.54 to 95.79 ha in 2013 and 2014, and from 2.54 to 138.67 ha in 2015 (Table 1). The standard deviation calculated for the area of UAA in all three analyzed years was at a similar level. This index remained at 12.36 in 2013, at 11.29 in 2014 and at 13.34 in the last of the analyzed years. The value of the coefficient of variation for all of the analyzed years ranged from 56\% to $62 \%$. This would indicate moderate variability in the group of farms divided per UAA.

Stocking density, expressed in LU $\cdot \mathrm{ha}^{-1} \mathrm{UAA}$, exhibited an upward trend with each analyzed year, at a constant mean of 0.58 in 2013, and 0.69 and 0.97 in 2014 and 2015, respectively. The high value of the coefficient of variation in all the analyzed years indicated high variability of the stocking density.

The economic size of the studied family farms expressed in EUR was highly diversified, and increased in each of the individual years of research. The average value of their economic size in 2013 was EUR 35,749, and in 2014 and 2015, EUR 38,981 and EUR 53,498, respectively. The minimum level of economic size in each year remained at a similar level. In 2014, farms were characterized by low variability of economic size, while in 2013 and 2015 a moderate variability was noted in this respect.

Labor inputs expressed in $\mathrm{mh} \cdot \mathrm{ha}^{-1}$ UAA remained at a similar level in all the analyzed years. The average value of labor inputs in 2013 was $319.37 \mathrm{mh} \cdot \mathrm{ha}^{-1}$ UAA, while in 2014 and 2015 it was 295.55 and 313.07, respectively. In 2013 and 2014, the farms were characterized by moderate variability of labor inputs, while in 2015 this index demonstrated high variability, at $296 \%$.

In all the analyzed years, total production expressed in PLN $\cdot \mathrm{ha}^{-1} \mathrm{UAA}$ remained at a similar level, i.e. $11,000 \mathrm{PLN} \cdot \mathrm{ha}^{-1} \mathrm{UAA}$. Only in 2013 the farms were characterized by moderate variability of total production, as in all other years, the index was highly variable.

The stocking density in particular groups of farms was highly diversified. The smallest average stocking density per ha of UAA was characteristic for "Very small" and "Very large" farms due to the chosen direction of production. "Very small" farms mainly carried out horticultural production, and "Very large" farms focused mostly on agricultural production. Farms from the "Medium-large" group had the highest stocking density in all the analyzed years. In this group, the stocking density remains at a similar level, from 0.50 to $0.51 \mathrm{LU} \cdot \mathrm{ha}^{-1} \mathrm{UAA}$ in each year of research. 
Usable agricultural area...

Table 1

General characteristics of the studied family farms

\begin{tabular}{|c|c|c|c|c|c|c|}
\hline $\begin{array}{l}\text { Year } \\
\text { of research }\end{array}$ & Specification & UAA (ha) & $\begin{array}{c}\text { Animal } \\
\text { stocking } \\
\left(\mathrm{LU} \cdot \mathrm{ha}^{-1}\right. \\
\text { UAA) }\end{array}$ & $\begin{array}{c}\text { Economic } \\
\text { size }(€)\end{array}$ & $\begin{array}{l}\text { Labor input } \\
\left(\mathrm{mh} \cdot \mathrm{ha}^{-1}\right. \\
\text { UAA) }\end{array}$ & $\begin{array}{c}\text { Total } \\
\text { production } \\
\left(\mathrm{PLN} \cdot \mathrm{ha}^{-1}\right. \\
\mathrm{UAA})\end{array}$ \\
\hline & Mean & 20.01 & 0.58 & 35749 & 319.37 & 11255 \\
\hline & Minimum & 2.54 & 0 & 4571 & 163.93 & 2998 \\
\hline \multirow[t]{5}{*}{2013} & Maximum & 95.79 & 2.2 & 287346 & 588.44 & 37474 \\
\hline & $\begin{array}{l}\text { Standard } \\
\text { deviation }\end{array}$ & 12.36 & 0.73 & 23703 & 228.96 & 11169 \\
\hline & $\begin{array}{l}\text { Coefficient } \\
\text { of variation }\end{array}$ & $62 \%$ & $126 \%$ & $66 \%$ & $72 \%$ & $99 \%$ \\
\hline & Mean & 20.17 & 0.69 & 38981 & 295.55 & 10192 \\
\hline & Minimum & 2.54 & 0 & 4168 & 148.68 & 2050 \\
\hline \multirow[t]{5}{*}{2014} & Maximum & 95.79 & 3.63 & 355742 & 561.07 & 30361 \\
\hline & $\begin{array}{l}\text { Standard } \\
\text { deviation }\end{array}$ & 11.29 & 0.92 & 15406 & 193.22 & 11283 \\
\hline & $\begin{array}{l}\text { Coefficient } \\
\text { of variation }\end{array}$ & $56 \%$ & $133 \%$ & $40 \%$ & $65 \%$ & $111 \%$ \\
\hline & Mean & 23.45 & 0.97 & 53498 & 313.07 & 11624 \\
\hline & Minimum & 2.54 & 0 & 4325 & 95.34 & 1576 \\
\hline \multirow[t]{3}{*}{2015} & Maximum & 138.67 & 2.58 & 450653 & 676.77 & 38680 \\
\hline & $\begin{array}{l}\text { Standard } \\
\text { deviation }\end{array}$ & 13.34 & 1.87 & 52939 & 925.81 & 23852 \\
\hline & $\begin{array}{l}\text { Coefficient } \\
\text { of variation }\end{array}$ & $57 \%$ & $193 \%$ & $99 \%$ & $296 \%$ & $205 \%$ \\
\hline
\end{tabular}

The largest economic size was characteristic for farms from the group with the largest UAA in 2015, i.e. "Very large", at EUR 44,890, 45,672 and 48,053 in the years 2013-2015, respectively. Such value of economic size allows classifying them as "Large" farms, according to economic size classes. Due to the fact that "Very Small" farms ran horticultural production, their economic size was comparable to "Medium-large" farms. The smallest economic size was characteristic for farms from the "Small" group. The average economic size of these farms in 2013 and 2015 was EUR 11,704 and 11,690, respectively.

The largest labor input, expressed in $\mathrm{mh} \cdot \mathrm{ha}^{-1} \mathrm{UAA}$, were characteristic for farms from the group with the smallest area of UAA and they were almost 40 times larger than the input incurred by farms from the "Very large" group. Such large labor inputs in this group of farms resulted from the horticultural production, which these farms often ran, and which requires a 
lot of manual labor. The lowest labor input occurred in the group of "Very large" farms, which is due to the production focus of the farms on agricultural production, which is characterized by a high degree of mechanization of work.

Total production, expressed in PLN per ha of UAA, was different in various groups of the studied farms. Together with the increase in the UAA in farms, the total production per 1 ha of UAA decreased. The highest value of total production was achieved by farms from the "Very small" group. The total production value identified for these farms was almost 20 times higher than on farms from the "Very Large" group, in which the lowest values occurred. In individual years, the total value of production in most groups remained at a similar level. Only in the "Very Small" group of farms a decrease was observed in total production value in 2015 by over $18 \%$, as compared to 2013 .

Table 2.

General characteristics of farm groups established per UAA

\begin{tabular}{|c|c|c|c|c|c|c|c|}
\hline $\begin{array}{l}\text { Group of } \\
\text { farms per } \\
\text { UAA } \\
\text { UAA6 }\end{array}$ & 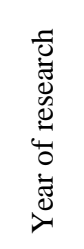 & 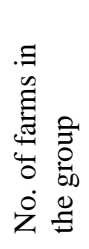 & 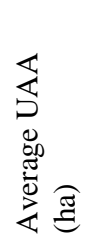 & 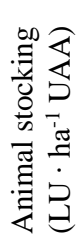 & 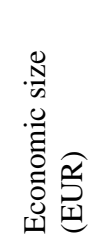 & 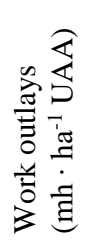 & 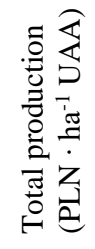 \\
\hline \multirow{3}{*}{$\begin{array}{l}\text { Very small } \\
(\leq 5 \mathrm{ha})\end{array}$} & 2013 & 16 & 2.39 & 0.23 & 27,080 & 2123 & 70,346 \\
\hline & 2014 & 15 & 2.34 & 0.43 & 28,429 & 2043 & 61,535 \\
\hline & 2015 & 16 & 2.32 & 0.23 & 26,463 & 1883 & 57,326 \\
\hline \multirow{3}{*}{$\begin{array}{c}\text { Small } \\
(5 \leq 10 \text { ha })\end{array}$} & 2013 & 89 & 8.10 & 0.42 & 11,704 & 427 & 7,304 \\
\hline & 2014 & 96 & 8.17 & 0.43 & 11,893 & 408 & 6,491 \\
\hline & 2015 & 92 & 8.10 & 0.36 & 11,690 & 417 & 7,278 \\
\hline \multirow{3}{*}{$\begin{array}{l}\text { Medium-small } \\
(10 \leq 20 \text { ha })\end{array}$} & 2013 & 259 & 14.59 & 0.41 & 16,771 & 264 & 5,784 \\
\hline & 2014 & 244 & 14.65 & 0.45 & 17,325 & 262 & 5,333 \\
\hline & 2015 & 239 & 14.55 & 0.40 & 16,582 & 262 & 5,340 \\
\hline \multirow{3}{*}{$\begin{array}{l}\text { Medium-large } \\
(20 \leq 30 \text { ha })\end{array}$} & 2013 & 145 & 24.48 & 0.50 & 26,461 & 168 & 5,476 \\
\hline & 2014 & 146 & 24.55 & 0.51 & 27,410 & 169 & 5,305 \\
\hline & 2015 & 144 & 24.25 & 0.50 & 27,259 & 170 & 5,164 \\
\hline \multirow{3}{*}{$\begin{array}{c}\text { Large } \\
(30 \leq 50 \mathrm{ha})\end{array}$} & 2013 & 130 & 36.57 & 0.47 & 37,708 & 114 & 5,202 \\
\hline & 2014 & 137 & 37.10 & 0.43 & 37,121 & 114 & 4,971 \\
\hline & 2015 & 148 & 37.91 & 0.47 & 39,691 & 115 & 3,849 \\
\hline \multirow{3}{*}{$\begin{array}{l}\text { Very large } \\
\text { (> 50 ha) }\end{array}$} & 2013 & 40 & 62.29 & 0.13 & 44,890 & 64 & 3,623 \\
\hline & 2014 & 41 & 64.73 & 0.12 & 45,672 & 60 & 3,849 \\
\hline & 2015 & 40 & 66.69 & 0.11 & 48,053 & 57 & 3,691 \\
\hline
\end{tabular}


Usable agricultural area...

The groups of farms, determined according to the area of UAA, were characterized by a large variability of material and energy expenditure efficiency indexes. The highest value of the index $\mathrm{E}_{\mathrm{Nmel}}$ was obtained by farms from the "Small" group; in the years 2013-2015 it was $2.14,2.10$ and 2.58, respectively (Table 3 ). Thanks to such material and energy expenditure efficiency, expressed by the index $\mathrm{E}_{\mathrm{Nmel}}$, farms from the "Small" group were also characterized by high efficiency, calculated by the ratio of the farmer's family income to material and energy expenditure, expressed as $\mathrm{E}_{\mathrm{NmeV}}$, at 0.64-0.94. As a result of production costs incurred, the farms in the "Very small" group were characterized by very low values of the efficiency index $\mathrm{E}_{\mathrm{NmeV}}$ : 0.03 in 2013, 0.14 in 2014 and 0.09 in 2015, despite the average value of index $\mathrm{E}_{\mathrm{NmeI}}$, at 1.57-1.74 (compared to the value of this index in other groups). This situation indicates too high production costs, which generate low income for the farmer's family.

Table 3.

Material and energy expenditure efficiency and the area of UAA in the studied years 2013-2015.

\begin{tabular}{|c|c|c|c|c|c|c|}
\hline $\begin{array}{l}\text { Group of farms } \\
\text { per UAA } \\
\text { UAA6 }\end{array}$ & $\begin{array}{l}\text { Year of } \\
\text { research }\end{array}$ & $\mathrm{E}_{\mathrm{NmeI}}$ & $\mathrm{E}_{\mathrm{NmeII}}$ & $\mathrm{E}_{\mathrm{NmeIII}}$ & $\mathrm{E}_{\mathrm{NmeIV}}$ & $\mathrm{E}_{\mathrm{NmeV}}$ \\
\hline \multirow{3}{*}{$\begin{array}{l}\text { Very small } \\
(\leq 5 \mathrm{ha})\end{array}$} & 2013 & 1.74 & 0.65 & 0.41 & 0.25 & 0.03 \\
\hline & 2014 & 1.62 & 0.75 & 0.54 & 0.27 & 0.14 \\
\hline & 2015 & 1.57 & 0.68 & 0.44 & 0.29 & 0.09 \\
\hline \multirow{3}{*}{$\begin{array}{l}\text { Small } \\
(5 \leq 10 \text { ha })\end{array}$} & 2013 & 2.14 & 1.55 & 1.06 & 0.92 & 0.78 \\
\hline & 2014 & 2.10 & 1.43 & 0.88 & 0.76 & 0.64 \\
\hline & 2015 & 2.58 & 1.91 & 1.29 & 1.12 & 0.94 \\
\hline \multirow{3}{*}{$\begin{array}{l}\text { Medium-small } \\
(10 \leq 20 \text { ha })\end{array}$} & 2013 & 1.82 & 1.26 & 0.89 & 0.79 & 0.71 \\
\hline & 2014 & 1.90 & 1.25 & 0.86 & 0.73 & 0.62 \\
\hline & 2015 & 2.02 & 1.38 & 0.96 & 0.81 & 0.70 \\
\hline \multirow{3}{*}{$\begin{array}{l}\text { Medium-large } \\
(20 \leq 30 \text { ha })\end{array}$} & 2013 & 1.65 & 1.06 & 0.74 & 0.68 & 0.65 \\
\hline & 2014 & 1.68 & 1.07 & 0.74 & 0.67 & 0.63 \\
\hline & 2015 & 1.89 & 1.23 & 0.84 & 0.75 & 0.69 \\
\hline \multirow{3}{*}{$\begin{array}{l}\text { Large } \\
(30 \leq 50 \text { ha })\end{array}$} & 2013 & 1.53 & 0.95 & 0.68 & 0.63 & 0.60 \\
\hline & 2014 & 1.67 & 0.97 & 0.66 & 0.60 & 0.55 \\
\hline & 2015 & 1.76 & 1.07 & 0.74 & 0.67 & 0.62 \\
\hline \multirow{3}{*}{$\begin{array}{l}\text { Very large } \\
(>50 \mathrm{ha})\end{array}$} & 2013 & 1.74 & 1.30 & 0.94 & 0.90 & 0.44 \\
\hline & 2014 & 1.68 & 1.18 & 0.81 & 0.78 & 0.77 \\
\hline & 2015 & 2.16 & 1.59 & 1.10 & 1.02 & 1.01 \\
\hline
\end{tabular}


The highest three-year mean material and energy expenditure efficiency, expressed as an index $\mathrm{E}_{\mathrm{Nmel}}$, were achieved by farms from the "Small" group, and the lowest, from the "Very small" and "Large" group (Fig. 1). Statistically significant differences in the value of this index were identified between farms from the "Small" and "Very small" groups and other farm groups. The lowest efficiency, regardless of the analyzed index, was characteristic for farms from the "Very small" group. However, the highest values of all indexes were obtained in the "Small" group of farms; the values of its indexes differed significantly from the other analyzed farm groups. It was observed that, along with an increase in the area of farms, there is a decrease in material and energy efficiency from "Small" to "Large" groups (Fig. 1).

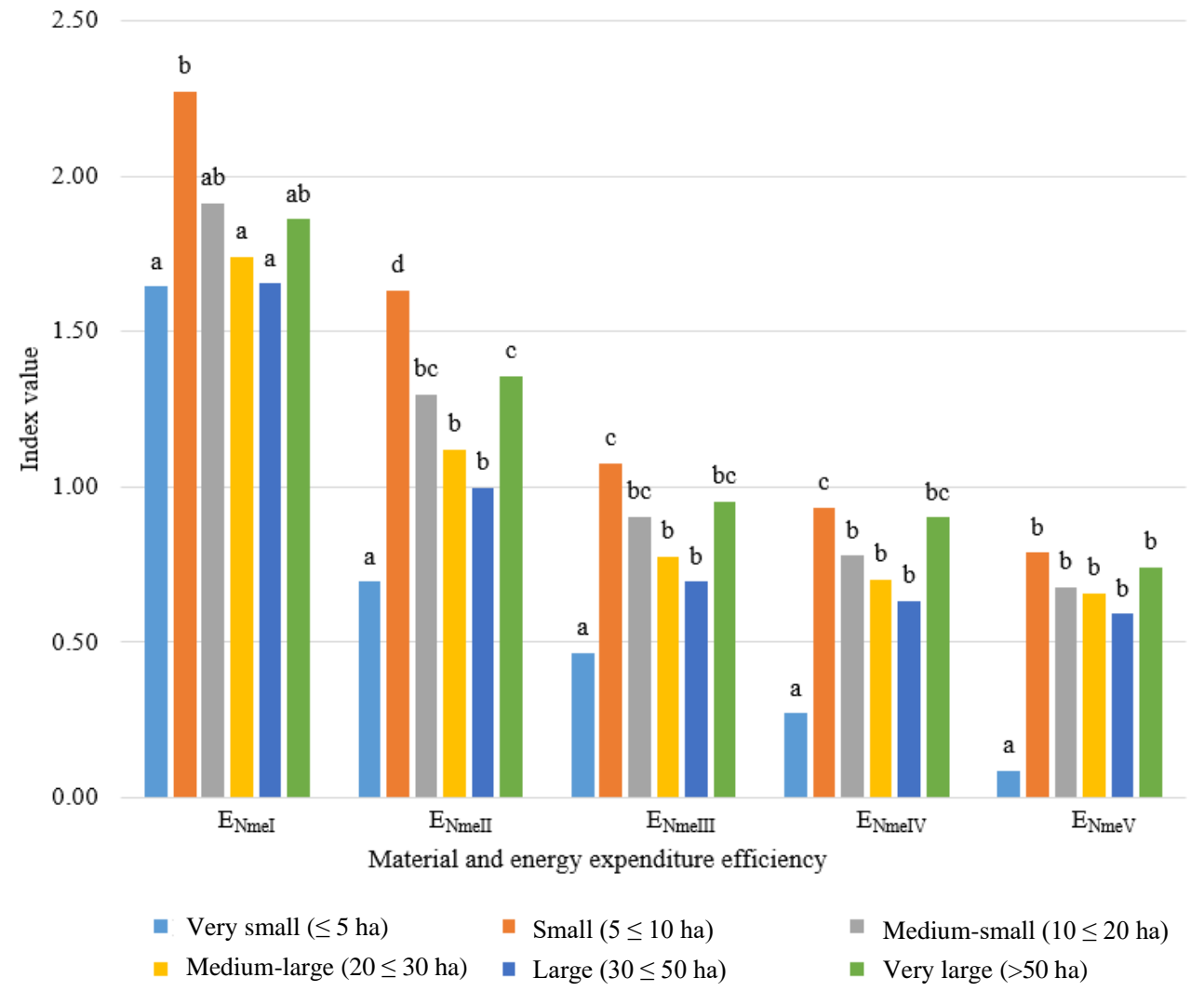

* values of indexes for individual groups of farms marked with the same letter do not differ statistically significantly at $\mathrm{p}<0.05$.

Figure 1. Material and energy expenditure efficiency indexes and the area of UAA - mean values from the years 2013-2015. 
The analysis of the results demonstrates that as the UAA increased, the difference between the values of calculated indexes decreased for: "Small", "Medium small", "Medium large" and "Large" farms. Sawa, (2008) observed that high material and energy expenditure in the farms with the smallest area (up to 20 ha of UAA), as well as in larger farms (20-60 ha of UAA), allow the social sustainability of the production process. Energy efficiency in ecological farms grouped by area of UAA was analyzed by Malaga-Toboła et al., (2020), who reported that larger farms use energy expenditure more efficiently. According to Sawa et al., (2004) energy expenditure per ha of UAA increases along with the increasing intensity of production organization, except that in larger farms they are relatively lower than in the smallest ones.

\section{Conclusion}

The analysis of the obtained results demonstrated that the area of UAA in farms determines their material and energy expenditure efficiency. It was identified that small farms with UAA of 5 to 10 ha are characterized by the highest material and energy expenditure efficiency. It was observed that the material and energy expenditure efficiency in "Small" farms with UAA ( $<=5$ ha) and "Very large", with UAA $(>50 \mathrm{ha})$ differs significantly from the efficiency determined for other farm groups. Material and energy expenditure is used the least efficiently in the farms with the smallest UAA.

\section{References}

Apergis, N., Aye, G.C., Barros, C.P., Gupta, R., Wanke, P. (2015). Energy efficiency of selected OECD countries: a slacks based model with undesirable outputs. Energy Economics, 51, 45-53.

Cooper, W.W., Seiford, L.M, Tone, K. (2007). Data envelopment analysis: a comprehensive text with models, applications, references and DEA-solver software. Boston, Kluwer.

Gołębiewska, B. (2007). Organizacja i zasoby gospodarstw rolniczych o zróżnicowanym poziomie nakładów zewnętrznych. Roczniki Naukowe SERiA, 9, 126-130

Gorzelany, J. (2010). Koszty i energochłonność procesów produkcji buraków cukrowych. Inżynieria Rolnicza, 1, 191-197.

Gorzelany, J., Puchalski, Cz., Malach, M. (2011). Ocena kosztów i nakładów energetycznych w produkcji kukurydzy na ziarno i kiszonkę. Inżynieria Rolnicza, 8, 135-141.

Hosseinzadeh-Bandbafha, H., Safarzadeh, D., Ahmadi, E., Nabavi-Pelesaraei, A. (2018). Optimization of energy consumption of dairy farms using data envelopment analysis - A case study: Qazvin city of Iran. Journal of the Saudi Society of Agricultural Sciences, 17, 217-228.

Kocira, S. (2013). Techniczna i technologiczna modernizacja gospodarstw rodzinnych $w$ procesie wdrażania rolnictwa zrównoważonego. Libropolis, Lublin.

Kocira, S., Depo, K., Szparaga, A., Findura, P. (2019). „Efficiency of material and energy expenditure and the direction of farms production", in: Farm machinery and processes management in sustainable agriculture., E. Lorencowicz, J. Uziak, B. Huyghebaert (eds.), Lublin, Instytut NaukowoWydawniczy Spatium, 365- 369.

Koesling, M., Hansen, S., Schueler, M. (2017). Variations of energy intensities and potential for improvements in energy utilisation on conventional and organic Norwegian dairy farms. Journal of Cleaner Production, 164, 301-314.

Komorowska, D. (2016). Efektywność ekologicznych gospodarstw mlecznych na tle ogółu indywidualnych gospodarstw mlecznych. Roczniki Naukowe Ekonomii Rolnictwa i Rozwoju Obszarów Wiejskich, 1, 46-52. 
Malaga-Toboła, U., Kuboń M., Kwaśniewski, D., Findura P. (2020). Effectiveness of Capital and Energy Expenditures in Organic Production. In: Wróbel M., Jewiarz M., Szlęk A. (eds) Renewable Energy Sources: Engineering, Technology, Innovation. Springer Proceedings in Energy. Springer, Cham.

Mohammadi, A., Omid, M. (2010). Economical analysis and relation between energy inputs and yield of greenhouse cucumber production in Iran. Applied Energy, 87, 191-196.

Ozkan, B., Akcaoz, H., Fert, C. (2004). Energy input-output analysis in Turkish agriculture, Renewable Energy, 29, 39-51.

Pawlak, J. (2016). Wartość produkcji a nakłady i koszty energii w rolnictwie. Zagadnienia Ekonomiki Rolnej, 1, 80-96.

Sawa, J. (2008). Nakłady materiałowo-energetyczne jako czynnik zrównoważenia procesu produkcji rolniczej. Inżynieria Rolnicza 5, 243-248.

Sawa, J., Parafiniuk, S., Kocira, S. (2004). Nakłady energetyczne w różnych systemach gospodarowania. Motrol, 6, 227-234.

Sorensen, C.G., Halberg, N., Oudshoorn, F.W., Petersen, B.M., Dalgaard, R. (2014). Energy Inputs and GHG Emissions of Tillage Systems. Biosystems Engineering, 120, 2-14.

Wójcicki, Z., Rudeńska, B. (2014). Efektywność nakładów materiałowo-energetycznych w gospodarstwie rolnym. Problemy Inżynierii Rolniczej 4, 57-70.

\title{
POWIERZCHNIA UŻYTKÓW ROLNYCH W GOSPODARSTWACH ROLNYCH A EFEKTYWNOŚĆ NAKŁADÓW MATERIAŁOWO-ENERGETYCZNYCH
}

\begin{abstract}
Streszczenie. W pracy przeprowadzono analizę efektywności nakładów materiałowo-energetycznych w 679 gospodarstw rolnych, których głównym źródłem dochodu była produkcja rolnicza. Analizy dokonano dla lat 2013-2015. Wyodrębniono 6 grup gospodarstw wg powierzchni użytków rolnych (UR). Celem pracy było określenie wpływu powierzchni użytków rolnych w gospodarstwach na efektywność nakładów materiałowo-energetycznych. Stwierdzono, że powierzchnia UR w gospodarstwach rolnych determinuje efektywność nakładów materiałowo-energetycznych. Zaobserwowano, że gospodarstwa małe o powierzchni od 5 do 10 ha UR charakteryzują się największą efektywnością nakładów materiałowo-energetycznych. Dowiedziono, że efektywność nakładów materiałowo-energetycznych w gospodarstwach o powierzchni UR z grup Małe ( $<=5$ ha) i Bardzo duże $(>50 \mathrm{ha})$ istotnie różni się od efektywności w pozostałych grupach gospodarstw. Najmniej efektywnie nakłady materiałowo-energetyczne wykorzystywane są w gospodarstwach najmniejszych obszarowo.
\end{abstract}

Słowa kluczowe: nakłady materiałowe, nakłady energetyczne, wskaźniki efektywności 